\title{
The Challenges Of Market Orientation Strategies Implementation In An Emerging Economy
}

Chris Mbah, (E-mail: cmbah@moc.edu), Mount Olive College Alphonso Ogbuehi, (E-mail: aogbuehi@bryant.edu), Bryant University Charles Blankson, (E-mail: BlanksoC@unt.edu), University of North Texas

\begin{abstract}
The purpose of this research was to explore the market orientation profiles and strategies implementations of a single Nigeria-based company, in the context of International Monetary Fund's structural adjustment programs. The design enabled broader understanding of the challenges facing an individual company adopting and implementing market orientation strategies in an unstable economy of a developing country. Based on lack of parsimonious market orientation definition, construct and assessment model in extant literature, this study assessed firm market orientation in this case, by the identification of market orientation instances, aggregation of properties of key market orientation components, and integration of environmental influences using proposed explicative market orientation model. Data processing and analysis was presented through multiple approaches. To facilitate this process, all market orientation properties and patterns identified in the in-depth interviews, and firm documents were presented in the list of market orientation action themes, using thematic aggregation and content analysis. Inter-functional involvements in firm market orientation and strategies implementations were assessed using simple correlation analysis. The findings of this study can help policy makers, international organizations and scholars in assisting individual organizations to more effectively navigate the adoption and implementations of market orientation strategies in an emergent economy undergoing market restructuring.
\end{abstract}

\section{INTRODUCTION}

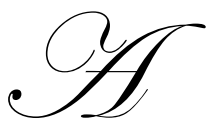

lthough many studies have investigated the impact of the SAP on the economies of developing countries (Blankson \& Appiah-Adu, 1998; Madagrassy, 1990; Madeley, 2000: Okoroafo, 1998), little research exist on individual firm adoption of the market orientation strategies in coping with the challenges of a SAP-induced business environment. To fill this gap, and increase an understanding of market orientation and strategies adoption challenges by an individual company in a SAP-induced environment, it is necessary to conduct this research.

Specifically, this research sought to gain broader insight into the market orientation process in a Nigerian based organization. It explored market orientation profiles and operationalization challenges of firm marketing strategies and practices, in developing country context.

\section{Problem Statement}

Nigeria, the sixth largest oil producing nation, like many developing countries of Sub-Saharan Africa, adopted the International Monetary Funds' (IMF) structural adjustment program (SAP) in 1986. While many notable Nigerian retailers, for example, United Trading Company (UTC), Kingsway Stores, and Leventis Stores experienced enormous operational difficulties during the SAP era, the Nigerian Breweries Plc experienced remarkable market growth, expansions and profitability. As a joint-venture between the people of Nigeria and Heineken of Holland, fifty- 
four percent $54 \%$ of the company's shares are held by Heineken of Holland while the remainder is held by Nigerians. Introduction of the structural adjustment programs (SAP) in Nigeria, however, ushered in various environmental challenges in the domestic marketplace. These conditions and other moderating externalities threatened market growth at the NB Plc. The company's survival and competitiveness in these austere times required effective operationalization of market orientation strategies and practices.

In order to gain broader insight into the market orientation profiles of this Nigerian based company, it is necessary to explore its market orientation strategies, practices and environmental challenges moderating market orientation adoption in the country context. Therefore, this research has two-fold objectives:

1. To explore individual firm market orientation strategies and practices, including SAP- induced environmental challenges.

2. To provide marketing practitioners and policy makers with more insight into individual firm market orientation profiles and environmental challenges of market orientation strategies adoption in an emergent economy.

Specifically, this study sought to address the following questions:

1. What specific market related changes occurred in the NB Plc?

2. How did these changes impact NB Plc's market orientation and strategies implementation?

3. How did different departments of the company operationalize individual components of the market orientation construct?

The determination and identification of market orientation variables (antecedents) is vital to establishing firm market orientation adoption and strategies implementation. According to Narver and Slater (1990), a business's magnitude of market orientation is the categorical aggregation of the three (3) components of market orientation. In addition to the exploration of these three (3) key variables of market orientation (customer orientation, competition intelligence and inter-functional collaboration), this study explored the influences of a fourth and critical component (environmental factors). Consequently, it established market orientation adoption and strategies implementation.

To show the magnitude of firm orientation profile, this study proposed a categorical aggregation of market orientation construct thus:

\section{Figure 1: Proposed Market Orientation (MO) Construct}

$\mathrm{MO}=\mathrm{f}(\mathrm{CO}, \mathrm{CI}, \mathrm{IC}) \mathrm{EI}$

Where: (MO) denotes market orientation, (CO) denotes customer orientation, (CI) denotes competitor intelligence, (IC) inter-functional coordination, (EI) environmental influences

Source: Mbah, Ogbuehi \& Blankson (2005)

The foregoing construct was used to identify and interpret the individual instances of orientation items which were recorded and observed as integral part of firm marketing strategies and practices. Data from firm records and interviews provided relatively incontestable descriptions of market orientation components, confirming or disconfirming market orientation strategies and practices for further analysis and reporting. The magnitude of the firm's market orientation profile was determined and ultimately reported based upon two methods explained in the methodology section of this research. The proposed market orientation construct in this study implied that (MO) definition involves the aggregation of customer orientation (CO), competitor intelligence (CI), inter-functional coordination (IC), with moderating environment influences (EI). 


\section{THE REVIEW OF LITERATURE}

While many scholars have provided abundant evidence in extant literature linking the adoption of market orientation with organizational performance, (Day, 1994, 1998; Jaworski \& Kohli, 1993; Narver \& Slater, 1990, 1995; Narver, Park \& Slater, 1994; Ruekert, 1992; Pelham, 1997, 2000), others postulate that organizational and environmental influences particularly in developing countries can further constrict the market orientation implementation (Sandri \& Williamson, 1989; Okoroafo \& Russow, 1993; Diamantopoulos \& Cadogan, 1996). These later arguments emphasize the need to further explore and understand the challenging tasks of effective market orientation development and strategies implementation in emergent economies undergoing economic and market restructuring.

To further this area of inquiry and knowledge, this study explored an individual firm's market orientation profiles. It is not for the purposes of drawing comparisons or correlations with others in terms of their levels of market orientation, but to maximize what can be learned about the market orientation adoption and strategies implementation, including the SAP-induced challenges in this particular intrinsic case. Perhaps the outcome can be adopted in managing similar organizations as developing and emerging nations embark upon continuing re-structural programs for competitive advantage in the $21^{\text {st }}$ century's global marketplace.

\section{Market Orientation Versus Marketing Orientation}

Many authors have debated the conceptual and application differences between the expressions marketoriented and marketing-oriented organizations (Perreault, 1984; Kohli \& Jaworski, 1990). While market orientation implies organization-wide adoption and operationalization of the marketing concept, marketing orientation focuses on the specific activities of the marketing unit. For the purposes of this study, we prefer the use of the all-inclusive term market orientation as advocated by (Kohli \& Jaworski, 1990; Narver \& slater, 1990). This position is justified in view of the firm-wide involvement in this case study.

In recent years, growing interests in the study of market orientation and its components, has led several researchers to contribute to its operational definition. In their exploratory study, Narver and Slater (1990) proposed the MARKOR scale - a one-dimensional construct, comprising of five (5) closely related components, including three (3) behavioral components and two (2) decision criteria. The Narver and Slater (1990) study was based on the logic and desire to create continuous sustainable and competitive advantage (SCA) towards attaining long-term customer satisfaction and profitability. See also (Aaker, 1989; Hall, 1980; Porter, 1985). The foregoing market orientation and culture studies were supported by Deshphande and Webster, (1989), and Kohli and Jaworski, (1990).

While an earlier study by Day and Wensley (1988) identified environmental moderator effects as vital, Narver and Slater (1990) argued that market orientation most likely related to business performance in general. It sparsely acknowledged environmental conditions may impact outcomes, and recommended further evaluation of behavioral components of (customer orientation, competitor orientation and inter-functional coordination).

While emphasizing the moderator effect, Narver and Slater (1990), also based their propositions and questions on such issues as market turbulence, technological turbulence, competitive intensity and strength of the economy. They concluded that market orientation was an important determinant of profitability, and confirmed the MO-performance relationship, citing examples such as degree of market orientation and individual firm growth.

\section{Market Orientation And Firm Environmental Factors}

Obviously the arguments by Narver and Slater (1990) assumed a continuum of market orientation scale (MARKOR), and that other environmental moderators remained constant. But since the marketing environments in developing countries are characterized by constant changes, many context-specific studies have been conducted to show specific influences, for example (Appiah-Adu, 1989; Balabanis, Stables \& Phillips, 1997; Blankson \& AppiahAdu, 1998; Okoroafo \& Russow, 1993). For the purposes of this project, and focusing on Nigeria’s SAP-induced 
business environment, we firmly posit that the changing state of country-specific environments will impact NB Plc's market orientation strategies and practices substantially.

\section{Market Orientation And Marketing Strategies In A SAP-Induced Environment}

An organization's success in today's dynamic business environment is more than ever before dependent on adaptation to changing and evolving customer needs. According to Kohli and Jaworski (1990), in a stable marketplace with unchanging customer needs and preferences, fewer strategic marketing changes will be required. This means that organizations, will adopt low degree of market orientation. The Nigerian market is far from being classified as stable, hence requiring constant re-constitution of marketing strategies. In a study of large-sized businesses, Day and Wensley (1991), concluded that there is a positive relationship between a turbulent market environment and market orientation as organizations strive to reduce uncertainties. Previous studies by Lusch and Laczniak (1987), also argued that businesses operating in highly volatile environments will be more responsive to changing marketplace needs. Such firms are therefore expected to be more market oriented. It is intended that the outcome of this study will reveal the extent of market orientation in the NB Plc, or lack of it therefore, in the context of Nigeria's volatile SAP environment.

\section{METHODOLOGY}

The organization under study was purposively selected from the list of 79 "Gold Award Winners" of the Nigeria Industrial and Exporters Directories (2001, 2002). To minimize the limitations associated with single respondent use, common in multi-firm and multi-industry studies, ten participating managers were selected from five company units and departments. For example, Marketing and Customer Services, Human Resources, Corporate Affairs, Accounting \& Finance, and Production, representing marketing and non-marketing managers of this single case study. This selection process was designed to reflect uniquely departmental input, identification and evaluation of market orientation properties, including inter-functional coordination and intelligence dissemination. Although many studies have relied on quantitative methods in establishing market orientation and performance relationship (Desphande, Farley \& Webster, 1993, Greenley, 1995; Kohli \& Jaworski, 1990, 1993; Narver \& Slater, 1990; 1994), the use of single deep case study method in qualitative exploration of obstacles for developing organizational market orientation, have been demonstrated by (Dyer \& Wilkins, 1991; Harris, 1996, 1998; Harris \& Piercy, 1999; Hunt, 1994).

\section{Instrumentation}

In view of the foregoing, the interview questions used in this research represent a qualitative adaptation and modification of the 20 items construct by Narver and Slater $(1990,1994)$. The purpose of this qualitative modification was to minimize the limiting responses imposed by use of quantitative measures such as the five or seven-item Likert scale in Nigeria's collectivist cultural context. This chosen method is well suited for obtaining in-depth narrative responses, especially for providing broad insight into firm market orientation strategies, with emphasis on the SAPinduced influences in the country context. Qualitative adaptation of modified versions of Narver and Slater (1990, 1994) construct in country-specific studies, are evidenced in (Appiah-Adu \& Ranchhood, 1998; Deng \& Dart, 1994; Gray et al, 1999; Kumar, Liu, Luo \& Shi, 2001; and Subramanian \& Yauger, 1999).

Although the adopted theoretical and conceptual Narver and Slater $(1990,1994)$ constructs have been tested for validity, the interview questions in this study were additionally submitted to two separate panels of four professors and researchers. These researchers were sourced from Long Island University, and Coppin State University in the United States, as well as Imo State University and Abia State University in Nigeria, comprising of individuals with backgrounds and expertise on marketing in Sub-Sahara Africa. These experts vetted the set of questions to establish further validity and credibility assurance, by advising and commenting on the questions design and re-designing, to ensure overall relevance and congruence with case context. 


\section{Validity And Reliability Of Measures}

We reduced the plausibility of threat to validity in this research by presenting a description of the market orientation construct and explicative market orientation model, grounded on the marketing concept. Both proposed construct and model extend Narver and Slater $(1990,1994)$, by emphasizing the environmental impacts on the market orientation process. The proposed model illustrated external and internal validity and assumptions guiding overall research reliability and potential for generalizability. Trochim (2001) refers to this as "wanting the measure to reflect the construct, the whole construct, and nothing but the construct" (p. 70). This study assumed there is an explanatory relationship between firm market orientation strategies implementation and the SAP-induced business environment. This relationship was captured in our proposed explicative market orientation model, operationalizing the market orientation components, while focusing on the SAP environment. While this model extended the (Narver \& Slater, 1990, 1994) market orientation model, whose validity and reliability has been proved in different studies, it also supported a recent study by Philemon (2003), which concluded by proposing an environmental model of market orientation focusing on organizational culture impacts on market orientation of firms.

Presuming a fundamental link between Nigeria's SAP-induced business environment and changes in individual firm market orientation adoption and strategies implementation, consequence case explanations about strategy changes reflected perceived changes in the country's re-structural policies and programs context. The case explanation identified some evidence of firm conception, adoption and justifications of market orientation strategies implementation and subsequent effect on overall firm marketing.

By also assuming an explanatory relationship between market orientation strategies implementation and the SAP environment, the conclusion of this single case study can, in specific instances of high proximal similarity, be used for extending theory-based analytic generalization of market orientation implementation and challenges in a developing country. The use of proximal similarity model (Trochim, 2001, p.43), for the purposes of limited naturalistic generalization may be useful for supporting international market entry arguments in the Nigerian market and other emergent economies currently implementing IMF's market re-structuring programs. Where a link between business environment and the ability of the individual firm in Sub-Saharan Africa to adopt and implement the market orientation strategies is established, (Appiah-Adu, 1998; Blankson \& Appiah-Adu, 1998; Okoroafo \& Kotabe, 1993; Philemon, 2003; Winston \& Dadzie, 2002), it can be concluded that this relationship will be positive. As such, the extent of changes and justifications of market orientation strategies implementation in this single case study remains a function of firm-wide understanding and commitment towards market orientation components and strategies, within the SAP context.

\section{Procedure And Logistical Challenges}

Facilitating researcher movements and safety across different firm locations in Lagos, Nigeria's chaotic mega-city, currently ranked $7^{\text {th }}$, with population of over 13.5 millions according to the Population Reference Bureau (2000) listings, requires careful logistical planning, for example travel modes, congestions, times, resources and security provisions and management. Also see Country Risk Analysis Scale (2002) lists of least safe places to do business, with Nigeria in consistently top tier position, underscoring security challenges facing foreign business travelers and visitors. These issues and other challenges such as the flexible time culture and business practices tended to whittle away the limited time period available for this research. Data was located, accessed, collected and recorded through multiple organizational gatekeepers by way of interviews and firm documents provided by participating heads of departments and units. The principal form of data collection, however, was interviewing of 10 departmental and unit directors, lasting about 45 minutes each. This was followed by two hours of focus-group exit interview. The purpose of conducting this exit interview was to pick up additional or newly emerging information, and to give participants the opportunity to retract any part of their interview responses. Thereafter, firm documents in the researcher's possession were gratefully returned.

Interview sessions content were captured by tape-recordings (with firm permission), jottings and reflective notes. Interview protocol included research questions designed to operationalize market orientation profiles and strategies. These tape-recorded interviews were transcribed and analyzed using categorical aggregations, patterns and 
direct interpretation methods suggested by (Denzin \& Lincoln, 2000; Stake, 1995; Trochim, 2001; Yin, 2003). Specific stages of this analysis comprised of development of market orientation themes, categorization of themes, thematic analysis, evaluation of thematic links and associations, using simple correlation analysis.

This combined approach provided in-depth analysis and definition of market orientation construct and boundaries of importance in this case, and also helped to identify and evaluate inter-functional involvement in firm market orientation implementations. On the whole, this data gathering methodology and analysis lead to increased insights into market orientation strategies implementation challenges in the NB Plc.

\section{DESCRIPTION OF CONTENT ANALYSIS AND RESULTS}

Traditionally, qualitative researchers do not possess distinct set of methods and have not followed systematic procedures in data analysis and presentation (Creswell, 1998; Denzin \& Lincoln, 2000; Miles \& Huberman, 1994; Patton, 2002; Stake, 1995; Yin, 2003). In light of this lack of parsimonious approach to analysis and inherent challenges associated with rejecting or supporting of data, these findings were influenced by deliberate search for market orientation (MO) confirmation or disconfirmation evidence, and adopted the following procedure and position:

1. Thematic analysis of firm market orientation components and word properties, including instances, patterns, and their relationships within firm functional units.

2. Discussion of firm marketing mix and strategies implementation in the SAP-induced environment.

Because this case was not a problem or hypothesis but rather an issue, the foci of this analysis, therefore, was not on problem resolution, but in-depth exploration and broader understanding. In view of this reality, our roles as researchers were to:

1. Evaluate the quality of (MO) activities and process in the NB Plc, portraying them in interpretive assertions.

2. Construct a clearer reality about challenges of (MO) strategies implementations in a SAP-induced environment of an emergent economy.

3. Give meaning and understanding of firm (MO) strategies through direct interpretation of individual (MO) instances of word properties and comments, aggregation of these instances and their inter-relationships.

First, this analysis reduced research data to themes, categories and patterns, and consequently used subjective evaluations to emphasize holistic market orientation discovery and description in the NB Plc. Finally, the result of these findings provided value insights into overall firm market orientation profiles and strategies implementations in the naturalistic context of Nigerian’s structural adjustment program business environment. relationships:

Thematic aggregation and analysis of firm market orientation (MO) components, instances, patterns and

To facilitate this mixed qualitative content analysis of market orientation components described in the foregoing, and as identified in in-depth interviews and firm documents, the following list of market orientation (MO) action themes in (table 1) were used in patterns identification, aggregation, content descriptions and subsequent correlations analysis.

First, in (table 1), market orientation components were coded under key themes. Interview text contents from ten participants, with two drawn from, and representing five different departments at NB Plc (Human Resource, Marketing, Finance \& Accounting, Production and Corporate Affairs) were analyzed. Subsequently, key market orientation components and word properties were aggregated, comprising of participants' responses to the 20-item interview questions, identified by (MO) word properties indicative of organization-wide and individual department's (MO) implementation activities 
Table 1: Market Orientation Components And Properties

\begin{tabular}{|c|c|c|c|}
\hline Customer Orientation & Competitor Intelligence & $\begin{array}{c}\text { Inter-Functional } \\
\text { Collaboration }\end{array}$ & Environmental Influences \\
\hline Customer service & Competitor awareness & Information technology & Environmental scanning \\
\hline Customer relations & $\begin{array}{c}\text { Marketing information } \\
\text { systems }\end{array}$ & Evaluation systems & Import substitution \\
\hline Relationship marketing & Marketing research & $\begin{array}{c}\text { Integrated marketing } \\
\text { communication }\end{array}$ & $\begin{array}{c}\text { Structural adjustment } \\
\text { program (SAP) }\end{array}$ \\
\hline Customer-driven & Competitive strategy & Human resources partners & $\begin{array}{c}\text { Foreign exchange (FOREX) } \\
\text { market }\end{array}$ \\
\hline Customer satisfaction & Competitive environment & Cross-functional integration & Localization \\
\hline Social responsibilities & Heightened competition & Internal marketing link & Local content requirement \\
\hline Consumerism & Time-based competition & $\begin{array}{c}\text { Just-in-time (JIT) production } \\
\text { and delivery }\end{array}$ & \begin{tabular}{c} 
Changing laws \\
\hline Ethical marketing
\end{tabular} \\
\hline Clientele & Strategic alliances & Managing diversity & Government assistance \\
\hline Industry data & Managing conformity & $\begin{array}{c}\text { Completely knocked-down } \\
\text { parts (CKDs) }\end{array}$ \\
\hline
\end{tabular}

Source: Mbah, Ogbuehi, Carter \& Blankson 2005

Furthermore in (table 2), participants' interview text contents were quantitatively presented using key (MO) components and recurring word properties, and as previously identified in action themes. While this thematic arrangement of (MO) components in interview texts content, (table 3), represented organization-wide market orientation profile and emphasis, it also revealed inter-functional market orientation activities, including volume and focus, rather than intensity Although the focus of this study was the exploration of overall firm (MO) profiles and strategies, rather than the determination of intensity of market orientation activities amongst firm departments, this revelation may be useful for the purposes of internal firm management, such as resources allocation, training and development decisions.

Table 2: Quantitative \& Thematic Market Orientation Interviews Text Analysis

\begin{tabular}{|c|c|c|c|c|c|}
\hline Participants/Dept & Theme 1 & Theme 2 & Theme 3 & Theme 4 & \\
\hline & $(\mathrm{CO})$ & $(\mathrm{CI})$ & (IC) & $(\mathrm{ENV})$ & Total \\
\hline 1 & 13 & 6 & 4 & 5 & 28 \\
\hline 2 & 24 & 12 & 9 & 15 & 60 \\
\hline 3 & 11 & 8 & 2 & 4 & 25 \\
\hline 4 & 12 & 9 & 5 & 6 & 32 \\
\hline 5 & 20 & 4 & 11 & 12 & 47 \\
\hline 6 & 7 & 19 & 7 & 4 & 37 \\
\hline 7 & 10 & 6 & 3 & 6 & 25 \\
\hline 8 & 15 & 8 & 4 & 9 & 36 \\
\hline 9 & 9 & 3 & 1 & 4 & 17 \\
\hline 10 & 16 & 10 & 6 & 10 & 42 \\
\hline Total & 137 & 85 & 52 & 75 & \\
\hline
\end{tabular}

* Aggregation of (MO) components and word properties.

This study assumed that Nigeria's structural adjustment programs changed both the general business environment (MO-antecedents) and consequently, the marketing strategy (MO-consequences) at the NB Plc. Given this assumption, this chapter employed simple correlation analysis in (table 4) to determine the strength of association between perceived environmental influences and other market orientation components.

The correlation analysis and summary in (table 3), indicate significant positive association between heightened environmental turbulence (ENV) and customer orientation (CO) components of firm market orientation 
(MO). This is derived from recurring instances of respondents' interview word properties and comments in theme one (CO) and theme four (ENV) at (r=0.959). Note that while customer orientation (CO) and inter-functional collaboration (IC) were also positively associated at ( $\mathrm{r}=0.695)$, this relationship was not as strong as (CO) and (ENV). These correlation outcomes are indicative of areas of increased firm marketing activities and responsiveness, which is consistent with interview responses. Consequently, it can also be inferred that firm marketing strategies focused on the components of customer orientation (CO), as well as inter-functional collaboration (IC) during periods of high market turbulence (ENV) brought about by the structural adjustment programs. Increased focus on inter-functional collaboration was also evident and emphasized by all respondents, and illustrated by total (MO) word properties count. Generally, there was evidence of increased competitor intelligence (CI) gathering and dissemination during turbulent markets, further enhanced by increased functional collaboration. See (table 3). This evidence directly confirmed increased use of intelligence generation, dissemination and responsiveness in turbulent markets, previously stated in (Kohli \& Jaworski, 1990).

Table 3: Thematic Market Orientation (MO) Components Correlation

\begin{tabular}{|c|c|c|c|c|}
\hline & Theme 1 & Theme 2 & Theme 3 & Theme 4 \\
\hline & (CO) & (CI) & (IC) & (ENV) \\
\hline Theme 1 & 1.000 & -0.105 & $0.695^{*}$ & $0.959^{* *}$ \\
\hline Theme 2 & & 1.000 & 0.319 & 0.016 \\
\hline Theme 3 & & & 1.000 & $0.752^{*}$ \\
\hline Theme 4 & & & & 1.000 \\
\hline
\end{tabular}

* Correlation is significant at the 0.05 level (2-tailed)

** Correlation is significant at the 0.01 level (2-tailed)

Correlation data was derived from recurring instances of (MO) word properties of firm interview text.

In (table 4) of firm marketing plan documents analysis, recurring (MO) word properties in (1996-2002) were identified and aggregated. The results show evidence of heightened activities in theme four (environment) during 1996-1998. These activities can be attributed to more challenging effects of early years of SAP adoption, marked by high market volatility and increased firm marketplace concerns. These challenges were marked by frequent changes in foreign exchange (FOREX) market, and governing laws. The "Asian Currency Crisis" of 1998-2000 may have also contributed to market volatilities in the African market regions.

Given increased government assistance, however, in 1999-2002, there was remarkable decrease in the concern for theme four (environment), as NB Plc marketing strategy and focus shifted to theme one (customer orientation), given increased production and growing product mixes and renewed competitive intelligence activities in theme two (CI) of (table 4).

Table 4: Selected Yearly Thematic (MO) Document Text Analysis

\begin{tabular}{|c|c|c|c|c|c|}
\hline Year & Theme 1 & Theme 2 & Theme 3 & Theme 4 & Total \\
\hline & (CO) & (CI) & (IC) & (ENV) & 80 \\
\hline 1996 & 12 & 9 & 12 & 47 & 39 \\
\hline 1997 & 19 & 12 & 12 & 45 & 90 \\
\hline 1998 & 21 & 18 & 8 & 17 & 54 \\
\hline 1999 & 12 & 7 & 11 & 17 & 69 \\
\hline 2000 & 28 & 13 & 15 & 12 & 65 \\
\hline 2001 & 22 & 16 & 85 & 206 & 77 \\
\hline 2002 & 32 & 84 & 17 & & \\
\hline Total & 146 & & 85 & & \\
\hline
\end{tabular}

* Data derived from recurring instances of (MO) word properties in firm marketing plan documents. 


\section{Major Findings}

1. The results showed that managerial characteristics such as leadership style and management emphasis on market orientation, affected firm market orientation adoption and implementation in all firm units. This also supports an early study by Akaah and Riordan (1988), and more recently, by Winston and Dadzie (2002), in the study of five sub-Sahara African countries, in a comparative study of Kenya and Nigeria respectively.

2. While the level of market turbulence, for example, frequent changes in foreign exchange and other laws affected marketing in the NB Plc, tribal, religion and other socio-cultural components such as language diversity, had little or no impact on market orientation in firm units.

3. Although heightened market turbulence was generally linked to market orientation adoption levels, Nigerian government assistance, for example removal of custom duties and tariffs on imported malted bailey and liberalized foreign exchange markets alleviated the challenges associated with marketing in austere times.

4. Regarding extent of government assistance that benefited the NB Plc, one respondent stated "the major assistance would be the removal of excise duties and ban on importation of packed beer products......we filled the vacuum with our Star and Heineken lager brand.” (p.20)

5. All firm units indicated increased levels of integrated marketing communication, market intelligence generation, dissemination and collaboration at different phases of firm market orientation strategies implementation.

6. Unlike Narver and Slater (1990), who relied on three main market orientation components (customer orientation, competitor intelligence and inter-functional collaboration), in their identification and aggregation of (MO) activities, this current study found that the fourth component (environment), strongly influenced overall market orientation adoption and implementation in the NB Plc.

7. More specifically, the structural adjustment program environment was positively associated with the customer orientation component, subsequently affecting changes in the marketing strategies at NB Plc, as discussed in the summary of firm marketing mix strategies section of this research findings.

The results of this study support both the proposed (MO) construct (figure 1) and explicative model of (MO). This is also consistent with Narver and Slater (1994), which identified market turbulence as being more positively linked to the marketing process (MO) rather than MO-performance relationship. This confirmation of the role of the fourth component in shaping MO strategies implementation at the NB Plc further underscored the importance of the proposed explicative model of MO, thereby validating overall purpose of this exploration of firm market orientation profiles.

\section{CONCLUSIONS}

This study's presentation of a single firm market orientation profiles should be viewed as an emerging and evolving work in identifying ways and means of assisting companies seeking to implement effective (MO) strategies in a developing country context. While it offers limited naturalistic generalization, it provides some insights into single firm challenges of (MO) strategies implementation in a SAP-induced business environment.

\section{Limitations And Recommendations For Future Research}

The foregoing finding was presented within the premise that insight and meaning gained from this case study can be subject to personal and professional values and biases. It is pertinent to view this research finding as an emerging, evolving work that is inextricably tied to the Nigerian SAP-induced environment. Consequently, future research directions should enable additional knowledge and meaning development and expansion in areas contributing towards broad and context-specific body of market orientation (MO) literature in emergent economies. Traditionally, the unique nature of this single Nigeria-based case study placed certain limitations on the generalizability of its findings. And even where limited naturalistic external comparison was possible in similar context and industry, for example, Nigeria's NB Plc and South African Breweries, potential effects of specific moderating environment(s) in the country context can further constrict generalization. See Winston and Dadzie (2002). While employing limited statistics, this study utilized in-depth exploration, analytical generalization and content analysis in results interpretation and discussions. 
To enable increased external generalization, the foci of future research into the market orientation adoption and strategies implementation in transitional economies should involve multiple cases. Perhaps, such research should also assume more comparative stance, while exploring causal effects of international and domestic factors influencing effective market orientation practices in the aftermath of IMF's economic program prescription implementations in emergent nations

\section{REFERENCES}

1. Akaah, I. \& Riordan, E. (1988). Applicability of marketing know-how in the Third World. International Marketing Review, Vol. 5 No. 1, Pp. 41-55.

2. Appiah-Adu, K. (1997). Market orientation and performance: Do the findings established in large firms hold in the small business sector? Journal of Euro-marketing. Vol. 6 Issue 3. Pp. 1-26.

3. Barrett, H. \& Weinstein, A. (1998). The effect of market orientation and organizational flexibility on corporate entrepreneurship. Entrepreneurship: Theory and Practice. Vol. 23. Issue 1. pp. 57(1).

4. Beam, R. A (2001). Does it pay to be a market-oriented daily newspaper? Journalism and Mass Communication Quarterly. Vol. 78. Issue 3, Pp.466-484.

5. Bitner, M. J. (1992). Services-cape: the impact of physical surroundings on customers and employees. Journal of Marketing, 56 (April), 57-71.

6. Blankson, C. \& Omar, O. E. (2002). Marketing practices of African and Caribbean small businesses in London, U.K. Qualitative Market Research: An International Journal. Vol. 5, No.2 Pp123-134.

7. Cadogan, J. W. \& Diamantopoulous, A. (1995). Narver and Slater, Kohli and Jaworski and the market orientation construct: Integration and internationalization. Journal of Strategic Marketing. Vol. 3, Pp.41-60.

8. Caruana, A., Ramaseshan, B., \& Ewing, M. T. (1999). Market orientation and performance in the public sector: The role of organizational commitment. Journal of Global Marketing. Vol. 12(3).

9. $\quad$ Creswell, J. W. (1998). Qualitative inquiry and research design: Choosing among five traditions. Thousand Oaks, CA: Sage.

10. Dadzie, K. \& Winston E. (2002). Market orientation of Nigerian and Kenyan firms: The role of top managers. The Journal of Business and Industrial Marketin, Vol. 17 (6) 471.

11. Day, G. S. \& Wensley R. (1988). Assessing advantage: A framework for diagnosing competitive superiority. Journal of Marketing, Vol. 52 No2, 1-20.

12. Denzin, N. \& Lincoln, Y. (2000). Collecting and interpreting empirical materials. Thousand Oaks, CA: Sage.

13. Deshpande, R. J., Farley, J. U., \& Webster, F. E. (1993). Corporate culture, customer orientation, and innovativeness in Japanese firms: A quadrad analysis. Journal of Marketing, 57, $23-27$.

14. Diamantopoulos, A. \& Cadogan, J. W. (1996). Internationalizing the market orientation construct: an indepth interview approach, Journal of Strategic Marketing, Vol. 4, pp. 23-52.

15. Dobni, c. B., \& Luffman, G. (2003). Determining the scope of impact of market orientation profiles on strategy implementation and performance. Strategic Management Journal. Vol. 24, Pp577-585.

16. Dyer, W. G. \& Wilkins, A. L., (1991). Better stories, not better constructs, to generate Better theory: A rejoinder to Eisenhardt. Academy of Management Review, Vol. 16, No. 3, Pp.613-19.

17. Gray, B. J., Greenley, G. E., Sheelagh, M. M., \& Matheson, P. K. (1999). Thriving in Turbulence. Journal of Market-focused Management. Vol. 4. Pp. 231-257.

18. Gregory, P. R. and Stuart, R. C. (1999). Comparative Economic Systems. $6^{\text {th }}$ ed., Boston, MA: Houston Mifflin Company.

19. Harris, L. C. (1996). Cultural obstacles to market orientation. Journal of Marketing Practice, Applied Marketing Science. Vol.2, No. 4, Pp. 36-52.

20. Harris, L. C. (2000). The organizational barriers to developing market orientation. European Journal of Marketing. Vol. 34. No. 5/6, Pp. 598-624.

21. Harris, L. C. (2002). Market orientation: Exploring a market-oriented approach. Journal of Market-focused Management. Vol. 5, 239-270.

22. Hunt, S. D. (1994). On rethinking marketing: our discipline, our practice, our methods. European Journal of Marketing, Vol. 28, No. 3, Pp.12-25. 
23. Ibeh, K. I. N. \& Brock, J. K (2004). Conducting survey research among organizational populations in developing countries. International Journal of Market Research, Vol.. 46 Quarter 3.

24. Jaworski, B. J. \& Kohli, A. K. (1993). Market orientation: Antecedents and consequences.Journal of Marketing, 57 (July), 53-70.

25. Jaworski, B.J., Kohli, A. K, \& Sahay, A. (2000). Market-driven versus driving markets. Academy of Marketing Science Journal. Vol. 28, Issue 1, Pp. 45-55.

26. Keegan, W. (1984). Multinational marketing management. Prentice-Hall, Englewood Cliff, NJ.

27. Kohli, A. K., Jaworski, B. J., \& Kumar. A. (1993). MARKOR: A measure of market orientation. Journal of Marketing Research. Pp.468-477.

28. Kohli, A. K. \& Jaworski B. J. (1990). Market orientation: the construct, research propositions, and managerial implications. Journal of Marketing, 54 (April) 1-8.

29. Liu, S. S., Luo, X., \& Shi, Y. (2001). Market-oriented organization in an emerging economy: A study of missing links. Journal of Business Research. Vol. 56. Pp481-491.

30. Madarassy, A. (1990). Private investment rebounds in developing countries. Finance and Development, Vol. 27 No2 (6), 48.

31. Matsuno, K. \& Mentzer, J. T (2002). The effects of strategy type on the market orientation-performance relationship. Journal of Marketing. Vol. 64, Issue. 4, Pp. 1-17.

32. McCarthy, E. J. \& Perreault, W. D., (1984). Basic Marketing, $8^{\text {th }}$ ed., Homewood, IL.

33. Miles, M. B. \& Huberman A. M. (1994). Qualitative data analysis (2 ${ }^{\text {nd }}$ ed.). Thousand Oaks, CA: Sage.

34. Morgan, R. E., Katsikeas, C. S., \& Appiah-Adu, K. (1998). Market orientation and organizational learning capabilities. Journal of Marketing Management. Vol. 14, Pp. 353-381.

35. Narver, J. C. \& Slater S. F. (1990). The effect of market orientation on business profitability. Journal of Marketing, Vol. 54, 20-35.

36. Nwankwo, S. \& Richards, D. (2004). Institutional paradigm and the management of Transitions: A subSahara African perspectives. International Journal of Social Economics. Vol. 31 (1/2) Pp.119-130.

37. Okoroafo, S. C. \& Kotabe, M. (1993). The IMF’s structural adjustment program and its Impact on firm performance: A case of foreign and domestic firms in Nigeria. Management International Review, Vol. 33 No. 2, Pp. 139-156.

38. Okoroafo, S. C. \& Russow, L. C. (1993). Impact of marketing strategy on performance: Empirical evidence from a liberalized developing country. International Marketing Review, Vol. 10 (1).

39. Patton, M.Q. (2002). Qualitative research and evaluation methods. Thousand Oaks, CA: Sage.

40. Pelham, A. M. (1997). Market orientation and performance: The moderating effects of product and customer differentiation, The Journal of Business and Industrial Marketing, Vol. 12 (5), pp. 276.

41. Pelham, A. M. (2000). Market orientation and other potential influences on performance in small and medium-sized manufacturing firms, Journal of Small Business Management, vol. 38 (1), 48-68.

42. Pitt, L., Caruana, A. \& Berthon, P. R. (1996). Market orientation and business Performance: Some European evidence. International Marketing. Vol. 13, Issue1, Pp. 5-19.

43. Porter, M. E (1985). Competitive advantage of nations. The Free Press.

44. Ruekert, R. (1992). Developing a market orientation: An organizational strategy perspective. International Journal of Research in Marketing, (9), 225-245.

45. Shapiro, B. P. (1988). What the hell is “market orientation?”. Harvard Business Review, 66. Pp. $119-25$.

46. Sandri, S. \& Williamson, C. (1989). Management and industrial relations strategies of multinational corporations in developing countries. Journal of Business Research, Vol. 18, No 3 (5), 179-193.

47. Slater, S. F. \& Narver J. C. (1990). Does competitive environment moderate the market orientationperformance relationship? Journal of Marketing, 58 (1), 46-55.

48. Slater, S. F. \& Narver. J. C. (1994). Market orientation, customer value, and superior performance. Business Horizon, (37), pp. 22-29.

49. Slater, S. F. \& Narver. J. C. (1994). Does competitive environment moderate the market orientationperformance relationship? Journal of Marketing. Vol. 58. pp. 46-55.

50. Slater, S. F. \& Narver, J. C. (1995). Market orientation and the learning organization. Journal of Marketing,Vol.59 (3), pp. 63-75.

51. Stake, R. E. (1995). The art of case Study research. Thousand Oaks, CA: Sage. 
52. Voss, G. B. \& Voss, G. (2002). Strategic orientation and firm performance in an artistic environment. Journal of Marketing. Vol. 64, Issue. 1, Pp.67-84.

53. Yin, R. K., (2003). Case Study Research: Design and Methods. $3^{\text {rd }}$ ed., Thousand Oaks, CA: Sage.

\section{NOTES}

